\title{
Impact of an ice storm on resident bird populations in eastern North America ${ }^{1}$
}

\author{
by Jonatan Blais ${ }^{2}$, Jean-Pierre L. Savard ${ }^{3}$ and Jean Gauthier ${ }^{3}$
}

The January 1998 ice storm was very dramatic, particularly in Québec, with five days of nearly non-stop freezing rain and temperatures below $0^{\circ} \mathrm{C}$. We compared results of Christmas Bird Counts (complete counts conducted during one day within a $12-\mathrm{km}$ radius by volunteers in winter) conducted before (1997-1998) and after (1999) the storm in control areas (16 sites) and in affected areas (15 sites). Abundance ratios (after/before) were significantly higher in control versus affected sites for Rock Dove Columba livia, Mourning Dove Zenaida macroura, Hairy Woodpecker Picoides villosus, Blue Jay Cyanocitta cristata, Black-Capped Chickadee Parus atricapillus and House Sparrow Passer domesticus. Paired -t- tests also indicated that the abundance of Brown Creeper Certhia americana and Downy Woodpecker Picoides pubescens was lower in affected sites following the storm. Only European Starling Sturnus vulgaris abundance increased significantly in affected sites. Species found in open habitats that forage mostly on the ground were less affected by the storm than tree foragers were. The effect of the storm on bird populations was quite significant and increased frequency of such storms could have drastic consequences on bird populations in the long term.

Key words: ice storm, birds, Christmas Bird Counts, winter survival, climate change

La tempête de verglas de 1998 a été particulièrement sévère, surtout au Québec avec sept jours continus de pluies verglaçantes et de températures sous les $0^{\circ} \mathrm{C}$. Nous avons comparé les résultats des Recensements d'Oiseaux de Noël (recensement d'oiseaux effectués en hiver pendant toute une journée à l'intérieur d'un rayon de $12 \mathrm{~km}$ par des bénévoles) réalisés avant (1997-1998) et après (1999) la tempête dans des secteurs non affectés (16 sites) et affectés (15 sites). Les ratios d'abondance (après/avant) étaient significativement plus élevés dans les sites non affectés que dans les sites affectés pour le Pigeon biset Columba livia, la Tourterelle triste Zenaida macroura, le Pic chevelu Picoides villosus, le Gaie bleu Cyanocitta cristata, la Mésange à tête noire Parus atricapillus et le Moineau domestique Passer domesticus. Des tests pairés de Student ont aussi révélé que l'abondance du Grimpereau brun Certhia americana et du Pic mineur Picoides pubescens était moins élevée dans les sites affectés après la tempête. Seulement une espèce, l'Étourneau sansonnet Sturnus vulgaris a augmenté de façon significative en nombre dans les sites affectés après la tempête. Les espèces qui fréquentent les milieux ouverts et qui s'alimentent surtout au sol ont été moins affectées par la tempête que les espèces s'alimentant dans les arbres. L'impact de la tempête sur les populations d'oiseaux a été important et l'augmentation de la fréquence de ces tempêtes pourrait avoir des conséquences drastiques à long terme sur les populations d'oiseaux.

\section{Introduction}

Ecologists are more attentive to the effect of climate on a variety of biological phenomena than ever before ( $\mathrm{Li}$ and Brown 1999). Among the different ways climate can affect the biology of wild species, extreme climatic events are recognised as one of the major causes of intense natural selection in wild populations (Endler 1986). The evolutionary effects of some types of extreme weather have been documented for Darwin's finches (Geospiza sp.) during intense drought (Grant and Grant 1993), and for Cliff Swallows (Petrochelidon pyrrhonota) after a late spring cold spell (Brown and Brown 1998).

Events that are short in duration, well defined spatially, and far beyond normal environmental extremes, are the most useful for documenting selection and may also represent a large part of the total natural selection imposed on a species (O'Donald 1973). Extreme weather events can affect managed wildlife populations and are thus interesting for conservation and wildlife management (Parmesan et al. 2000). Although the biological importance of extreme climatic events is recognised, few quantitative studies have documented the direct effects on

${ }^{1}$ Paper presented at the Ice Storm 1998 Forest Research Conference, Ottawa, October 19-22, 2000.

${ }^{2}$ Biology Department, Laval University, Ste-Foy, Québec G1K 7P4.

${ }^{3}$ Canadian Wildlife Service, 1141, Route de l'Église, P.O. Box 10100, Sainte-Foy, Québec, G1V 4H5. E-mail : jean-pierre.savard@ec.gc.ca bird populations. This is likely due to their unpredictable nature, which makes the collection of data before the perturbation impossible to plan. Therefore, responses of wild populations to extreme weather should be measured at every opportunity to understand their real evolutionary role, and to adjust, if necessary, management and conservation programs. This seems especially true in the context of global warming when these climatic disturbances are likely to increase (Watson et al. 1996). Global climate changes are now strongly suspected to affect the biology of birds, particularly by affecting their breeding phenology and survival (Crick et al. 1997, Forchhammer et al. 1998). Many descriptive reports of bird mortality after climatic disturbances have been published (Gessaman and Worthen 1982, Wood 1998), but few have quantified the impact at a population level and on a large geographical scale. In northern regions with seasonally severe climates, availability of food during winter is considered to be one of the main factors affecting survival rates and subsequently limiting populations of resident birds (Fretwell 1972). In addition, foraging time is decreased in winter due to shorter days and can be further restricted by heavy snow or ice cover (Cooper and Swanson 1994).

In January 1998, a very intense ice storm hit eastern North America during five days, covering everything with ice for about two weeks. This storm is considered to have been the most important ice storm to occur in the region in the last 50 years (Fig. 1; 


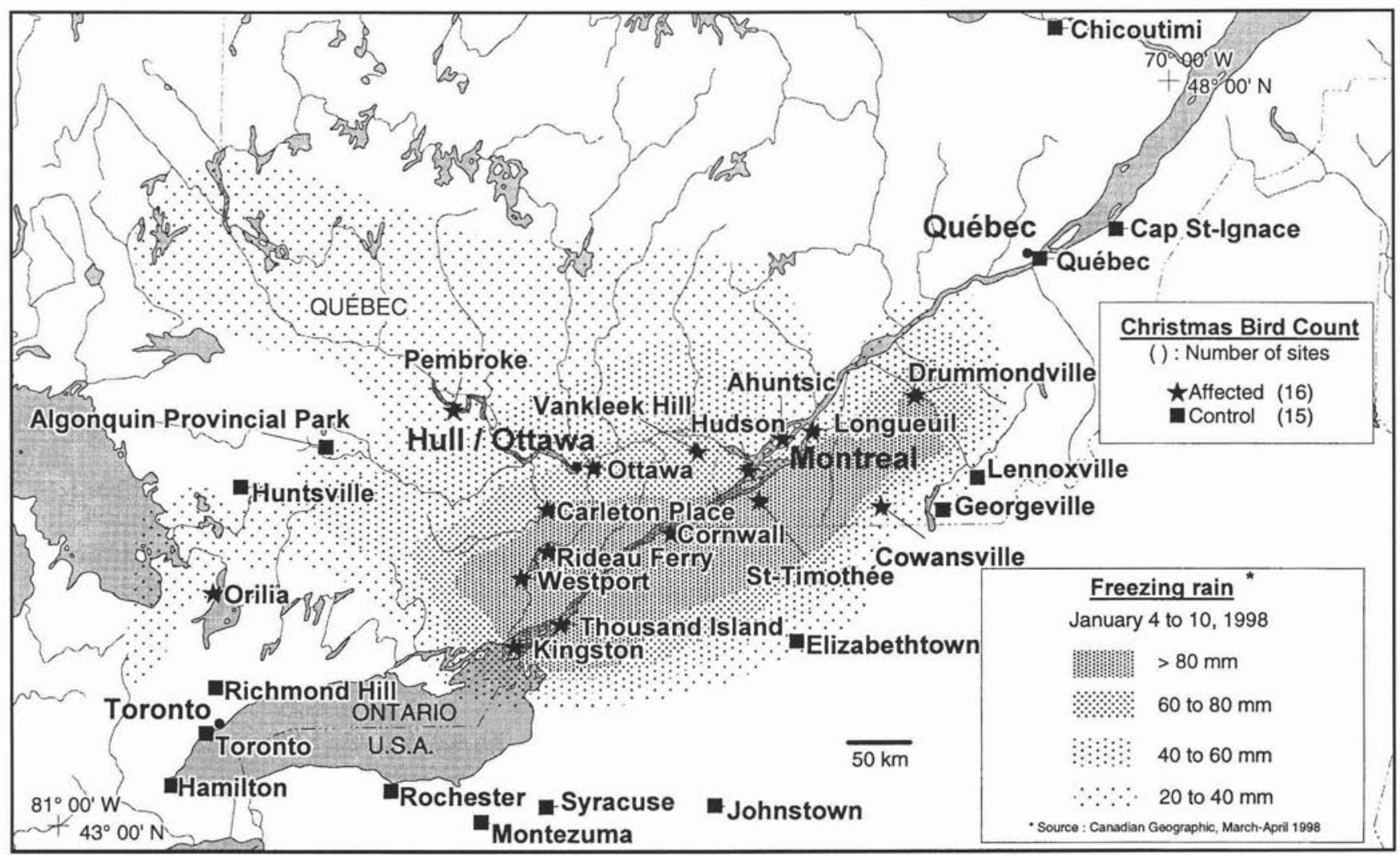

Fig. 1. Location of $\mathrm{CBC}$ sites used to evaluate the impact of the February 1998 ice storm on birds in Quebec, Ontario and the Northeastern U.S.

Milton and Bourque 1999). Long-lasting ice storms are among the most stressful types of precipitation on birds, because in addition to enveloping foraging substrate under a layer of ice, the rain-wet bird plumage increases thermoregulation costs (Elkins 1988). In 1951, a very important ice storm killed an entire population of Carolina Chickadee Parus carolinensis in Tennessee, and that population was only one-half of its original number three and a half years later (Goodpasture 1955). We used the data of the Audubon Christmas Bird Count (CBCs) to study the impact of the ice storm of January 1998 on resident bird populations. We predicted that if the ice storm greatly reduced winter bird survival, count sites situated inside the affected area should have smaller numbers of resident birds the year following the storm than control sites situated outside this area.

\section{Study Area and Methods}

The area affected by the ice storm covered part of southwest Quebec, southeast Ontario, northern New York, New England, New Brunswick and Nova Scotia (Fig. 1). Count sites chosen were in Quebec, Ontario, and New York State, because the storm was most severe in these jurisdictions and several count sites were available (Fig. 1).

Christmas Bird Counts have taken place each year since 1900 in the USA and Canada. All CBCs occur within a $24.1-\mathrm{km}$ diameter circle, and are done by volunteers under the supervision of an experienced compiler. Each count is conducted during a single day chosen by the compiler within two weeks of 25 December. For a given CBC site, the surveys before and after the ice storm were conducted at approximately the same date each year (within two or three days). Participants record the species and number of individuals of all birds seen. Various measures of efforts are compiled. We used the number of party-hours (the numbers of hours spent in the field by a party of volunteers during a count) to normalise results by dividing the number of individuals of a given species seen during a given count by the total number of party-hours for this count $(\mathrm{Zxy}=\mathrm{Nxy} / \mathrm{Hy}$, where $Z x y=$ normalised number of species $\mathrm{x}$ for count $\mathrm{y}, \mathrm{Nxy}=$ number of individuals of species $x$ seen for count $y$, and $\mathrm{Hy}=$ total party-hours for count y), which is the most-often used measure of effort in study using CBCs data (Bock and Root 1981).

Count sites were chosen on the basis of the number of participants, which had to be as high as possible to get good coverage of plots and regular from year to year to ensure a relatively constant effort and minimise possible bias due to data adjustment for party-hours. Necessity dictated that control sites were in the periphery of the affected zone. We chose 16 sites inside and 15 outside the affected zone (Fig. 1). Only sedentary and relatively abundant species were studied (Rock Dove Columba livia, Mourning Dove Zenaida macroura, Downy Woodpecker Picoides pubescens Hairy Woodpecker Picoides villosus, Blue Jay Cyanocitta cristata, Black-capped Chickadee Parus atricapilus, Red-breasted Nuthatch Sitta canadensis, Whitebreasted Nuthatch Sitta carolinensis, Brown Creeper Certhia americana, European Starling Sturnus vulgaris, and House Sparrow Passer domesticus). Eruptive species were not considered.

Three years of data were analysed, two years before (December 1996 / January 1997 and December 1997 / January 1998), and the year just following (December 1998 / January 1999) 
Table 1. Meteorological data for the period of the storm (January 4-9), and the week after. Mean from three airports (Dorval, St-Hubert and Mirabel) situated inside the affected area in Québec

\begin{tabular}{|c|c|c|c|c|}
\hline $\begin{array}{c}\text { Date } \\
\text { (January 98) }\end{array}$ & $\begin{array}{c}\text { Temperature } \\
{ }^{\circ} \mathrm{C}\end{array}$ & $\begin{array}{c}\text { Precipitation } \\
\text { Freezing } \\
\text { rain }(\mathbf{m m})\end{array}$ & $\begin{array}{l}\text { Precipitation } \\
\text { Snow }(\mathrm{cm})\end{array}$ & $\begin{array}{c}\text { Wind } \\
\text { (average } \\
\text { speed, } \mathrm{km} / \mathrm{h} \text { ) }\end{array}$ \\
\hline 4 & -2.3 & 0.0 & 0.4 & 20.5 \\
\hline 5 & -5.9 & 14.9 & 2.8 & 16.8 \\
\hline 6 & -4.0 & 14.1 & 2.1 & 9.8 \\
\hline 7 & -5.2 & 5.3 & 2.0 & 12.5 \\
\hline 8 & -3.6 & 11.4 & 10.7 & 26.8 \\
\hline 9 & -2.3 & 10.4 & 5.9 & 20.7 \\
\hline 10 & -0.3 & 0.0 & 1.1 & 20.5 \\
\hline 11 & -7.4 & 0.0 & 0.0 & 18.1 \\
\hline 12 & -11.2 & 0.0 & 0.0 & 4.9 \\
\hline 13 & -5.3 & 2.4 & 7.0 & 24.0 \\
\hline 14 & -15.3 & 0.0 & 0.0 & 16.2 \\
\hline 15 & -15.5 & 0.0 & 6.1 & 19.5 \\
\hline 16 & -10.4 & 0.0 & 0.4 & 27.8 \\
\hline 17 & -11.6 & 0.0 & 0.0 & 18.8 \\
\hline
\end{tabular}

Table 2. Comparison (paired t-test) of bird abundance (mean number of birds / party-hours $\pm \mathrm{SE}$ ) before and after the ice storm in affected and in control areas. (* significant at $\alpha \leq 0.10)$

\begin{tabular}{|c|c|c|c|c|c|c|c|c|}
\hline \multirow[b]{2}{*}{ Species } & \multicolumn{4}{|c|}{ Affected sites } & \multicolumn{4}{|c|}{ Control sites } \\
\hline & Before & After & P-value & $\%$ change & Before & after & P-value & $\%$ change \\
\hline Rock Dove & $12.37 \pm 2.26$ & $11.90 \pm 2.45$ & 0.36 & & $6.41 \pm 1.20$ & $7.74 \pm 1.55$ & $* 0.10$ & $\uparrow(21 \%)$ \\
\hline Mourning Dove & $3.81 \pm 0.57$ & $4.20 \pm 0.90$ & 0.48 & & $3.29 \pm 0.44$ & $4.70 \pm 1.05$ & 0.12 & \\
\hline Downy Woodpecker & $0.57 \pm 0.06$ & $0.46 \pm 0.05$ & *0.07 & $\downarrow(19 \%)$ & $0.62 \pm 0.09$ & $0.62 \pm 0.07$ & 0.99 & \\
\hline Hairy woodpecker & $0.45 \pm 0.06$ & $0.29 \pm 0.05$ & $*<0.001$ & $\downarrow(35 \%)$ & $0.35 \pm 0.06$ & $0.27 \pm 0.03$ & 0.12 & \\
\hline Blue Jay & $3.27 \pm 0.40$ & $1.87 \pm 0.29$ & $*<0.001$ & $\downarrow(43 \%)$ & $1.99 \pm 0.38$ & $1.94 \pm 0.32$ & 0.83 & \\
\hline Black-capped Chickadee & $7.98 \pm 0.65$ & $6.57 \pm 0.78$ & $* 0.03$ & $\downarrow(18 \%)$ & $8.19 \pm 0.79$ & $8.70 \pm 1.20$ & 0.60 & \\
\hline Red-breasted Nuthatch & $0.15 \pm 0.03$ & $0.11 \pm 0.06$ & 0.18 & & $0.46 \pm 0.17$ & $0.47 \pm 0.19$ & 0.81 & \\
\hline White-breasted nuthatch & $0.66 \pm 0.07$ & $0.59 \pm 0.08$ & 0.21 & & $0.57 \pm 0.06$ & $0.54 \pm 0.10$ & 0.70 & \\
\hline Brown Creeper & $0.08 \pm 0.01$ & $0.05 \pm 0.01$ & $* 0.03$ & $\downarrow(37 \%)$ & $0.11 \pm 0.02$ & $0.09 \pm 0.02$ & 0.50 & \\
\hline European Starling & $14.49 \pm 2.27$ & $19.27 \pm 3.50$ & $* 0.09$ & $\downarrow(33 \%)$ & $37.21 \pm 12.35$ & $47.12 \pm 15.93$ & 0.34 & \\
\hline House Sparrow & $9.78 \pm 1.82$ & $8.39 \pm 1.58$ & $* 0.04$ & $\downarrow(14 \%)$ & $5.94 \pm 1.23$ & $6.15 \pm 1.15$ & 0.73 & \\
\hline
\end{tabular}

the ice storm. Note that the counts of December 1997 / January 1998 occurred before the storm. Therefore, a reproductive season occurred between the ice storm and data collection after the storm. The mean of the two years before the ice storm was used as a "before" measure $((1996-97+1997-98) / 2)$, and data from the counts of December 98/ January 99 as an "after" measure (1998-99). We used the mean of two years before the storm instead of only the 1997-98 data to reduce the effect of possible unusual and unknown events that could have made the numbers data for certain counts less reliable in 1997-98.

We analysed data in the following ways. First we compared the abundance of each species before and after the storm in both affected and unaffected (control) areas using paired T-tests. We used a one-way significance level for affected areas as we predicted a decrease in those areas following the ice storm and a two-way level for control areas. For the two species that increased after the storm in the affected area (Mourning Dove and European Starling), we used a two-way level of significance. Second, in affected and control areas we tested for each species, whether the ratio (number after/number before) differed from 1 using a regular T-test. Third, we compared this ratio between affected and control areas using a regular T-test. The significance level was established at $10 \%$ as we dealt with relatively low sample sizes and believed that a $5 \%$ level would have been too conservative.

We calculated species fasting endurance at $0^{\circ} \mathrm{C}$ using the formula: fasting endurance (in days) $=$ energy stored $(0.15 \mathrm{w} \times 39.8$ $\times 0.94)$ / standard metabolic rate $\left(\mathrm{kJ} /\right.$ bird-day) at $0^{\circ} \mathrm{C}$, where $\mathrm{w}=$ wet weight in grams (Kendeigh 1969, Ketterson and Nolan 1976). We assumed that $15 \%$ of wet body weight represented the amount of fat for all species (Ketterson and Nolan 1976, Kullberg 1998).

\section{Results}

Six species (Downy Woodpecker, Hairy Woodpecker, Blue Jay, Black-capped Chickadee, Brown Creeper, and House Sparrow) decreased significantly the year after the storm in the affected areas but not in control areas (Table 2). The only species that increased on affected sites was the European Starling, while its numbers remained unchanged on controls (Table 2). In control sites, only Rock Dove relative abundance increased the year after the storm. Changes in Red-breasted and White-breasted Nuthatches were not significant in either ice-damaged or control sites but were qualitatively more pronounced on damaged sites suggesting a possible effect of the storm (Table 2). Mourning Dove populations did not change following the storm on either control or affected sites.

On ice-damaged sites, ratios after/before were below 1.0 for Hairy Woodpecker, Blue Jay, Black-capped Chickadee, Redbreasted Nuthatch and above 1.0 for Mourning Dove and European Starling (Table 3). On control sites four ratios were greater than 1.0 those of Rock Dove, Mourning Dove, European Starling, and House Sparrow (Table 3). Comparisons between the sites indicated that ratios of Rock Dove, Mourning Dove, 
Table 3. Comparison of the abundance ratio (number of birds after/number of birds before) within sites (whether ratios in affected and control sites differ from 1) and between sites (whether ratios differ between affected and control sites) (unpaired t-tests)

\begin{tabular}{|c|c|c|c|c|c|c|}
\hline \multirow[b]{3}{*}{ Species } & \multicolumn{3}{|c|}{$\begin{array}{l}\text { After/before ratios comparisons } \\
\text { within sites }\end{array}$} & & \multirow{2}{*}{\multicolumn{2}{|c|}{$\begin{array}{c}\text { After/before ratios comparisons } \\
\text { between sites }(\mathrm{df}=29)\end{array}$}} \\
\hline & \multicolumn{2}{|c|}{ Affected sites $(n=16)$} & \multicolumn{2}{|c|}{ Control sites $(n=15)$} & & \\
\hline & Ratios & P-value & Ratios & P-value & P-value & $\%$ change \\
\hline Rock Dove & $0.96 \pm 0.11$ & 0.34 & $1.49 \pm 0.24$ & $* 0.03$ & $* 0.04$ & $\downarrow(36 \%)$ \\
\hline Mourning Dove & $1.18 \pm 0.13$ & $* 0.09$ & $1.46 \pm 0.19$ & $* 0.01$ & $* 0.10$ & $\downarrow(19 \%)$ \\
\hline Downy Woodpecker & $0.91 \pm 0.13$ & 0.24 & $1.14 \pm 0.15$ & 0.18 & 0.12 & \\
\hline Hairy woodpecker & $0.65 \pm 0.07$ & $*<0.001$ & $0.90 \pm 0.10$ & 0.18 & $* 0.02$ & $\downarrow(28 \%)$ \\
\hline Blue Jay & $0.59 \pm 0.07$ & $*<0.001$ & $1.10 \pm 0.14$ & 0.23 & $*<0.01$ & $\downarrow(47 \%)$ \\
\hline Black-capped Chickadee & $0.82 \pm 0.07$ & $*<0.01$ & $1.06 \pm 0.10$ & 0.27 & $* 0.02$ & $\downarrow(23 \%)$ \\
\hline Red-breasted Nuthatch & $0.73 \pm 0.20$ & $* 0.09$ & $1.07 \pm 0.29$ & 0.40 & 0.16 & \\
\hline White-breasted nuthatch & $0.93 \pm 0.11$ & 0.26 & $1.06 \pm 0.17$ & 0.36 & 0.27 & \\
\hline Brown Creeper & $0.90 \pm 0.20$ & 0.31 & $1.36 \pm 0.40$ & 0.19 & 0.15 & \\
\hline European Starling & $1.46 \pm 0.20$ & $* 0.03$ & $1.80 \pm 0.37$ & $* 0.05$ & 0.21 & \\
\hline House Sparrow & $0.93 \pm 0.08$ & 0.20 & $1.74 \pm 0.53$ & $* 0.08$ & $* 0.08$ & $\downarrow(47 \%)$ \\
\hline
\end{tabular}

Hairy Woodpecker, Blue Jay, Black-capped Chickadee, and House Sparrow were greater in control areas than in affected areas indicating again a greater reduction in numbers in ice-damaged areas for these species (Table 3 ).

The fasting endurance of the species studied ranges from one day for the Brown Creeper to eight days for the Rock Dove. At $0^{\circ} \mathrm{C}$, Black-capped Chickadees, Red-breasted Nuthatches, White-breasted Nuthatches, House Sparrows and Downy Woodpeckers have less than two days of fasting endurance whereas Blue Jays, European Starlings, Hairy Woodpeckers and Mourning Doves have less than four days. These values are calculated for an ambient temperature of $0^{\circ} \mathrm{C}$, which, of course, was not the constant value of temperature for the period of the storm nor for the days following it (Table 1). Daily temperatures averaged below $0^{\circ} \mathrm{C}$ during most of the storm, and became even colder the week after (Milton and Bourque 1999). Freezing rain was virtually non-stop during the five days of the storm (from January 5 to January 10, 1998). These climatic conditions are much more adverse than just an ambient temperature of $0^{\circ} \mathrm{C}$, especially if chilling factors are considered. Thus, our calculated fasting endurance times are likely higher than actual fasting times for the species studied in these conditions. Thus, climatic conditions associated with the ice storm had the potential to cause significant mortality in the species studied.

\section{Discussion}

Some controversy exists about the usefulness of $\mathrm{CBC}$ data (Kenaga 1965, Robbins and Bystrak 1974) mostly because they are collected by thousands of people with different expertise. When comparing $\mathrm{CBC}$ data to more rigorously collected birddensity data, Bock and Root (1981) found that species, except extremely rare or unusually gregarious ones, are adequately represented in CBC data. None of the species discussed in this paper is particularly rare, and except for the European Starling, Rock Dove, and House Sparrow, is not unusually gregarious. These last three species are so abundant and widespread in urban areas, where count effort is the most important, that we consider them to be well represented in CBCs.

The fact that eight species out of eleven studied either decreased after the storm with no change outside or had lower ratio after/before in affected sites than in controls, strongly suggests that the ice storm of January 98 in eastern North Amer- ica had a significant impact on resident bird populations. This is not surprising considering the fasting times endurance calculated and an estimated period of food scarcity of about two weeks for most species. Mortality or emigration were two main consequences of these conditions. Given the duration and scale of the storm and the usual bird sedentary behaviour associated with such conditions, emigration out of the affected area is highly unlikely for most species. However, to detect an impact with a crude tool like Christmas Bird Counts, even after a reproductive season, is alarming, and suggest that the impact on birds was major. Our analysis does not allow causeeffect conclusions, but it is difficult to imagine another factor affecting populations of the eleven different species studied.

Except for Nuthatches, all tree foragers species (Downy and Hairy Woodpeckers, Blue Jay, Black-capped Chickadee, and Brown Creeper) decreased the year following the storm in affected sites, while no change was detected in controls. The reason why Nuthatches seem to have been less affected than other species is unclear. Food caching is common and frequent behaviour for both nuthatches (Grubb and Waite 1987, Woodrey 1991), but also exists for some of the other species, i.e., Blue Jay and Black-capped Chickadee (Petit et al. 1989, Cooper and Swanson 1994). It may be a more important behaviour for nuthatches, but with significant ice cover, even food caches in the bark of tree trunks and under branches (Petit et al. 1989) were probably difficult to use. There was, however, a tendency for lower number of nuthatches in affected versus control areas. Possibly, CBC data are inappropriate for surveying nuthatches because of their relatively low abundance and even distribution within their preferred habitat. Physiological differences in adaptation to starvation between nuthatches and affected species, or a superior capacity to find or obtain food under ice cover, are also possible explanations that need further investigations.

Other species (Rock Dove, Mourning Dove, European Starling, and House Sparrow) live in more open habitats (urban or agricultural), and often feed on the ground. House Sparrow populations decreased significantly after the storm, but effects on Rock Dove and Mourning Dove seem different. Immigration may have contributed to Rock Dove population increases in controls or, populations on control and ice-damaged areas may have increased before the storm, and that increase was stopped in the ice-damaged area. Rock Doves may have 
been partially sheltered from the freezing rain by roosting under human-made structures. Their large size probably contributed to their greater survival as well (Saether 1989). This is suggested by the low P-value of paired t-test on control sites (0.12), almost indicating a significant population increase at $\alpha \leq 0.10$, even among controls. One site, Richmond Hill, with an increase of $292 \%$ compared to a mean of $46 \%$ for all control Rock Dove sites reduced the power of the test by increasing variability within sites.

Mourning Dove populations on control and damaged sites did not change after the ice storm. Nevertheless, the significant difference between control and ice-damaged site ratios could indicate emigration outside the affected zone, as Mourning Doves are known to move long distances in search for food during winter (Tomlinson 1993). However, the movements reported were in reaction to cold weather and not freezing rain, which makes emigration out of the affected area nearly impossible. Thus, the pattern seems similar for the two Dove species (increase in controls and stability in ice-damaged sites). However, both Dove species had a higher ratio after/before in control sites than in affected ones, suggesting that they may have been affected by the ice storm. European Starling was the only species to increase in affected sites, while no change was detected in controls. Even if the differences between before and after were higher in controls than in affected sites, the increase was not significant. This may be due to the high variability among controls, possibly reflecting gregarious habits of the species,. The ability of Starlings to feed on many different foraging substrates and their varied and opportunistic diet (Cabe 1993) may explain why these birds were able to go through the storm so well.

Thus, it seems that ground foragers that occupy open habitats were less affected by the storm than species that forage in trees. Ground foragers are also considered more opportunistic and adaptable in their foraging sites, diets, and habitat requirements, which often includes the urban environment. The House Sparrow may have been affected more than the three other species because of its inferior fasting endurance capacities and/or higher sedentariness.

House Sparrow had the greatest difference from control ratios. Blue Jays populations declined the most following the storm (43\%) despite the fact that they had one of the highest fasting capacities (four days). Unlike cavity roosting species, they remained exposed to the harsh weather conditions at night, which may have increased their sensitivity to hypothermia. However, Hairy Woodpeckers which roost in cavities and have an estimated fasting endurance of three days were similarly affected. Relation of body size to ability to survive food shortages in wintering birds is still debated. One of the most important question is the relationship between fat level (which is the measure used here to estimate fasting endurance) and metabolism. Higher fat levels are thought to increase metabolic rate, which in turns increases food demands and foraging time (Lima 1986, Houston and McNamara 1993). Thus, the advantage credited to larger species in our calculated fasting endurance could be highly overestimated. This could explain why species with apparently high fasting capacities were affected more than others with lower capacities were.

Our findings suggest that the 1998 ice storm and potentially increased frequency of extreme weather, related possibly to global climate change, could have important biological consequences for resident birds. Indeed, climate change could act as a strong selective pressure on wildlife populations, with very different effects depending on the species. The hypothesis that selection is strongest when survival is critical during times of food scarcity requires study (Tinbergen 1957). Eight species out of eleven were negatively affected by the ice storm and it is interesting to note that it is the species adapted to the human environment (Mourning Dove, Rock Dove, and European Starling) that seem to have been the least affected. Extreme weather events are known to have drastic effects on bird populations (Newton 1998) and this was likely the case during the 1998 ice storm in Quebec and Ontario.

\section{Acknowledgements}

We thank Environment Canada (Division des sciences atmosphériques et enjeux environnementaux) for unpublished meteorological data and Michel Melançon for production of the figure. We are also grateful to John M.C. Peterson, Terry Spratt, Jeanne L. Ryan, Bill Purcell, Peter J. Good, Martine Lemieux, Tony Bigg, Mike Peterson, Denis Gervais, Gerhard W. Leubner, Marc Lecompte, Pamela Hunt, Pierre Wery, Mark Jennings, Camille Dufresne, Jean Pelletier, Michael Jacques, George Lachaine, Manson Fleguel, Ron Tozer, and Bruce Di Labio, all volunteer compilers who sent us their unpublished data. Thanks to Jean-François Giroux, Yves Maufette, R. A. Lautenschlager and an anonymous reviewer for their useful comments.

\section{References}

Bock, C.E. and T.L. Root. 1981. The Christmas Bird Count and avian ecology. Studies in Avian Biol. 6: 17-23.

Brown, C.R. and M.B. Brown. 1998. Intense natural selection on body size and wing and tail asymmetry in Cliff Swallows during severe weather. Evolution 52(5): 1461-1475.

Cabe, P.R. 1993. European Starling (Sturnus vulgaris). In A. Poole and F. Gills. (eds.). The Birds of North America, No. 48. The Academy of Natural Sciences, Philadelphia, The Am. Ornithologists' Union, Washington, D.C.

Cooper, S.J. and D.L. Swanson. 1994. Seasonal acclimatization of thermoregulation in the Black-capped Chickadee. Condor 96: 638-646.

Crick, H.P.Q., C. Dudley, D.E. Glue and D.L. Thomson. 1997. UK birds are laying eggs earlier. Nature 388: 526.

Elkins, N. 1988. Weather and bird behavior. T E A D Poyser, Calton, England.

Endler, J.A. 1986. Natural selection in the wild. Princeton Univ. Press, Princeton, NJ.

Forchhammer, M.C., E. Post and N.C. Stenseth. 1998. Breeding phenology and climate. Nature 391: 29-30.

Fretwell, S.D. 1972. Populations in a seasonal environment. Princeton University Press, Princeton, New Jersey, USA.

Gessaman, J.A. and G.L. Worthen. 1982. The effect of weather on avian mortality. Utah State University.

Goodpasture, K.A. 1955. Recovery of a Chickadee population from the 1951 ice storm. The Migrant. Tennessee Ornithological Society. 26(2): 21-23.

Grant, B.R. and P.R. Grant. 1993. Evolution of Darwin's finches caused by a rare climatic event. Proc. R. Soc. Lond. B. 251: 111-117. Grubb, T.C., Jr. and T.A. Waite. 1987. Caching by Red-breasted Nuthatches. Willson Bull. 99(4): 696-699.

Houston, A.I. and J.M. McNamara. 1993. A theoretical investigation of the fat reserves and mortality levels of small birds in winter. Ornis Scandinavica. 24: 205-219.

Kenaga, E.E. 1965. Are birds increasing in numbers? Bull. Ent. Soc. Amer. 11: 81-83. 
Kendeigh, C.S. 1969. Tolerance of cold and Bergmann's rule. Auk. 86: $13-25$.

Ketterson, E.D. and V. Nolan Jr. 1976. Geographic variation and its climatic correlates in the sex ratio of eastern-wintering Darkeyed Juncos (Junco hyemalis hyemalis). Ecology. 57: 679-693.

Kullberg, C. 1998. Does diurnal variation in body mass affect takeoff ability in wintering willow tits? Animal Behaviour. 56(1): 227-233.

Li, S.-H. and J.L. Brown, 1999. Influence of climate on reproductive success in Mexican Jays. Auk 116(4): 924-936.

Lima, S.L. 1986. Predation risk and unpredictable feeding conditions: determinants of body mass in birds. Ecology 67: 377-385.

Milton, J. and A. Bourque, 1999. Climatological account of the January 1998 ice storm in Québec. Scientific Report, Atmospheric Environment Service, Atmospheric Sciences and Climate Monitoring Division, Environment Canada, Québec Region. 87 p.

Newton, I. 1998. Population limitation in birds. Academic Press. Toronto.

O'Donald, P. 1973. A further analysis of Bumpus' data: the intensity of natural selection. Evolution 27: 398-404.

Parmesan, C., T.L. Root and M.R. Willig. 2000. Impacts of extreme weather and climate on terrestrial biota. Bull. Amer. Meteo. Soc. $81: 443-450$.
Petit, D.R., L.J. Petit and K.E. Petit. 1989. Winter caching ecology of deciduous woodland birds and adaptations for protection of stored food. Condor 91(4): 766-776.

Robbins, C.S. and D. Bystrak. 1974. The winter bird survey of central Maryland, USA. Acta Ornithol. 14: 254-271.

Saether, B.E. 1989. Survival rates in relation to body weight in European birds. Ornis Scandinavica 20 : 13-21.

Tinbergen, N. 1957. The functions of territory. Bird Study. 4: 14-27.

Tomlinson, R.E. 1993. Migration. In Dove (T.S. Barkett, M.W. Sayre, R.E. Tomlinson, and R.E. Mirarchi (eds.). Ecology and management of the Mourning. p. 57-80. Stackpole Books, Harisburg, PA. Watson, R.T., M.C. Zinyowera and R.H. Moss. 1996. Climate change 1995-Impacts, adaptations and mitigation of climate change: Scientific-technical analysis. Contribution of Working Group II to the Second Assessment Report of the Intergovernmental Panel on Climate Change, Cambridge University Press, NY. p. 878.

Wood, J. 1998. The effects of an abnormally cold winter spell on Southland birds. Notornis. 45 : 126-128.

Woodrey, M.S. 1991. Caching behavior in free-ranging Whitebreasted Nuthatches: the effect of social dominance. Ornis Scandinavica 22: 160-166. 